THE TOTAL SOLAR ECLIPSE, APRIL 28, I9r. $N$ EWS of the results of this eclipse arrived in England from Vavau on Saturday afternoon, April 29, in the form of a cable through Reuter's Agency from Mr. P. Baracchi, Government astronomer at Melbourne, Australia. He reported that the observations of the eclipse were considerably interfered with by passing clouds, and that the results were only partially successful.

No news regarding the experience of the English parties observing at Vavau was available until Sunday morning, April 30, when Sir Norman Lockyer received a cable from Dr. Lockyer, sent by wireless from H.M.S. Encounter, at Vavau, to H.M.S. Pegasus, at Auckland, thence by cable, stating that the expedition from the Solar Physics Observatory had not been successful, in consequence of bad weather. With regard to the two most important spectroscopic instruments-a 6-inch prismatic camera with four large objective prisms of $45^{\circ}$ angle, and a concave grating spectrograph of to feet radius of curvature--poor results have been secured by the first; photographs of the corona, with the two large coronagraphs of I6 feet and 8 feet focal length, were obtained, but of inferior quality.

A general description is given of the visual observations made of the form of the corona, from which we learn that it was of the typical minimum type, with long equatorial extensions. The general description of the eclipse is that it was not a dark one, and in consequence comparatively few stars were observed during totality.

The second English party under Father Cortie has been also unfortunate, but as yet no news is to hand regarding the experience of the German and American astronomers who proposed to occupy one or more of the islands to the north-east of Vavau.

In an interesting letter received from Dr. Lockyer he emphasises the generous and enthusiastic help afforded to the expedition by the Australian authorities. Mr. H. A. Hunt, the Commonwealth Meteorologist, at the request of the Government, invited Dr. Lockyer to inspect the site of the new Solar Physics Observatory, which is to be established near the new capital; this is a little more than twelve hours' railway journey from Sydney. It will be the only southern observatory having solar observations as its prime duty, and it fills a longitude gap between India and the United States. It is therefore anticipated that the results from such a locality will be of the greatest importance.

Towards the end of March the heavy equipment taken out from England was safely stored on board H.M.S. Encounter, of the Australian squadron, and the official party, in company with that of Father Cortie and Mr. Baracchi, sailed from Sydney on March 25, reaching Vavau on April 2. On the way arrangements would have been made for the organisation of the various parties, taking charge of each section of observation. Captain Colomb, R.N., assisted the expedition in every way, and from a telegram received last week we learned that on the call for volunteers more than Ioo of the ship's company simnified their willingness to take part in the observations. Parties would be formed for sketching the corona, observations of shadow bands, landscape colours, aids for the working of each of the large instruments, timekeeners, \&c. By means of pictures of . rmer eclipses which have been successfully observed and general descriptions by the astronomers in charge, all the members of these different sections would soon be rendered conversant with their individual duties. On landing steps would first be taken to select the most suitable site: then the ground would NO. 2 I66, VOL. 86] be roughly surveyed, and the positions selected for the pillars of the large instruments. This done, more accurate observations of the meridian line would be made, so that each instrument could be adjusted exactly in the proper orientation. When the instruments were satisfactorily installed and protected, periodical drills would be instituted, when all the operations, down to the smallest detail, would be practised, exactly as if the eclipse were really taking place. After two or three of these drills everyone becomes verv proficient in their duty, and it is only such unavoidable misfortune as has attended the present occasion which can prevent good observations from being secured.

The latest information is that a second message has been received from $\mathrm{Mr}$. Baracchi stating that some of the results of the Australian party are better than was at first anticipated. Thirty pictures of the corona have been obtained. Charles P. Butler.

\section{STANDARD BREAD.}

$A$ LMOST every people boasting the rudiments of $\mathrm{A}$ agriculture makes use of cereals as part of its food. The cereals comprise all grains or corn-bearing plants, and are grasses which by long cultivation and selection have developed a maximum of food material with a minimum of husk. Wheat, barley, oats, rye, maize, millet, and rice are the principal cereals, and the first four have an extraordinarily wide geographical distribution. The following is the average composition of cereals :-

$\begin{array}{lllllll} & & & & & & \begin{array}{c}\text { Per } \\ \text { cent. }\end{array} \\ \text { Proteins } & \ldots & \ldots & \ldots & \ldots & . . & 10-12 \\ \text { Carbohydrates } \ldots & \ldots & \ldots & \ldots & \ldots & 65-75 \\ \text { Fat } \ldots & \ldots & \ldots & \ldots & \ldots & \ldots & 0.5-8 \\ \text { Mineral salts } & \ldots & \ldots & \ldots & \ldots & \ldots & 2 \\ \text { Water } \ldots & \ldots & \ldots & \ldots & \ldots & \ldots & 10-12\end{array}$

Maize and oats are the richest in fat, wheat and rye contain respectively $I^{*} 7$ and $2 * 3$ per cent. of fat, while rice contains the maximum of carbohydrate and the minimum of protein and fat. Regarded as a diet the cereals contain a large excess of carbohydrate and a deficiency of protein and fat. Wheat and rye are alone suitable for bread-making; this is due to the fact that they contain a peculiar protein "glutin," which becomes viscid when mixed with water, and determines the binding properties of the dough. Glutin does not exist as such in the grain or flour, but is developed by the interaction in the presence of water of two proteins, gliadin and glutinin.

For the preparation of flour the grain is ground or milled, and in the process, which by means of

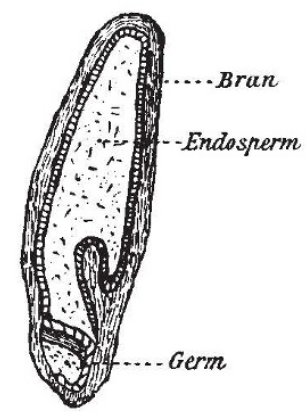

FIG. 1.-Diagram of structure of wheat grain.

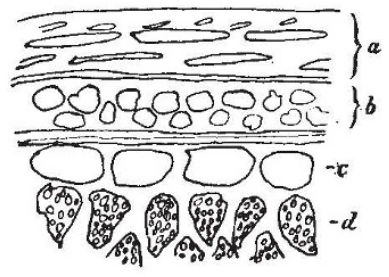

FIG. 2.-Diagram of layers of wheat grain. modern machinery in the iron roller mills has been brought to an extraordinary degree of perfection, various constituents of the grain are 
separated. A grain of wheat consists of (1) an outer envelope or husk, which constitutes the bran, (2) the kernel or endosperm, and (3) the germ (see Fig. I). The husk has an outer cuticle from which delicate hairs spring (Fig. 3), under which are three other lavers, the two outer consisting of elongated cells (Fig. 2, a), the third of well-defined rounded cells (Fig. 2, b). Then comes the envelope of the seed proper, the "testa" or "episperm," under which is a layer of large quadrilateral "cerealin" cells (Fig. 2, c), which encloses the endosperm; the latter consists of numbers of large cells with delicate walls filled with starch granules (Fig. 2, d). The husk, constituting the bran, consists mainly of cellulose with pigment and

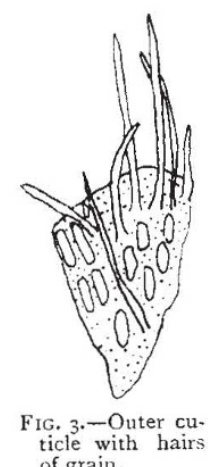

of grain.

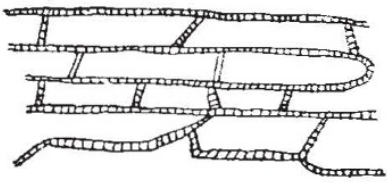

F1G. 4.--Inner skin or epicarp of grain

mineral salts, the endosperm consists largely of starch, and the germ, relatively a small portion of the whole, is rich in protein and fat. In the process of milling the grain is broken up and various "mill products" are obtained. The outer coats yield bran, fine pollards, sharps, and middlings, the germ is removed as offal, while ordinary flour is derived almost solely from the endosperm. The flour itself is divided into a larger portion, "bakers" or "households," and a smaller, very white and poor in protein, known as "patents," from which genuine Vienna bread and the best class of fancy breads and pastries are made. The semolina, derived from the central part of hard wheat, and rich in glutin, is also lacking in white flour.

It will thus be seen that ordinary white flour and white bread made therefrom contain little or none of the bran, germ, and semolina, and valuable food con-

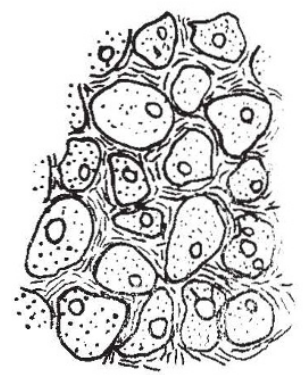

FIG. 5.--Large-celled endocarp layer of grain.

stituents-mineral matter and protein of the bran and semolina, and fat and protein of the germ-are lost. Wholemeal bread is therefore richer in the nutritive constituents and has more flavour; but is darker in colour than white bread, owing partly to the inclusion of the bran and partly to an interaction by which No. 2 I66, VOL. 86$]$ dextrin and sugar are formed which undergo darkening in the oven. Wholemeal bread is, however, apt to be irritating on account of the cellulose and silica of the outer coat, but by removal of the outer layers of the husk the irritant material may be excluded, and the valuable mineral, protein, and fatty constituents of the inner branny coat, semolina, and germ, are retained. Such a tlour constitutes the "8o per cent. flour " employed in making the so-called "standard" bread. The term "8o per cent. flour" means that a wheat a bushel of which weighs $64 \mathrm{lb}$. yields 80 per cent. flour. In the old method of milling the wheat is ground between stones, the flour being separated by sifting, and in this war some of the "offal" is retained; hence the term "stone-ground."

"Standard" bread is distinctly cream-coloured, and contains pale brown particles derived from the branny coats of the grain. It has more flavour and is moister than ordinary white bread, and contains more phosphates and other mineral salts. Microscopically various branny constituents can be recognised, $e . g$. cuticle with hairs (Fig. 3), inner skin or epicarp (Fig. 4), and large-celled endocarp layer (Fig. 5), and these figures are reproduced from actual drawings of a sample of "Standard" bread examined. There is doubtless some difference of opinion as to the relative values of ordinary and "Standard" flour, and the bread made therefrom. The roller mills cleanse the wheat in a very efficient manner. Chemical analysis, except as regards salts, shows little difference between the two; "standard" bread may even be slightly poorer than ordinary bread in protein, owing to the greater percentage of moisture. On the whole, however, we think there can be little doubt that "Standard" flour and bread are to be preferred. Their use will also tend to revive wheat growing and the small miller in Eng land.

\section{THE HOME LIFE OF THE SHANS. ${ }^{1}$}

THE Shan States under the control of the Government of Burma form two groups, the northern and the southern, separated for some distance by the Nam Tu or Myitnge River in the eastern portion of the province. Ethnologically, the Shans are a branch of the great Tai people, "the free," who at present exercise sovereignty only in Siam. The affinities of the branches of this people are obscured by the bewildering variety of names which disguises their identity, while the dialects are mutually incomprehensible, and, as if this were not enough, are recorded in at least six forms of written character. Even the origin of the name Shan is a puzzle, the only reasonable explanation being that of Sir J. G. Scott, who points out that they were known to the Burmese as Tarok or Taret, and possibly gained their present title from their Chinese designation, Han Jen. Our knowledge of them is derived from the accounts of earlier ravellers like Dr. Richardson, Captain Macleod, and Sir H. Yule: from the translation of tribal chronicles by Mr. Nev Elias and Sir I. G. Scott, and of Chinese authorities by Mr. G. H. Parker; and, in particular, from the monograph on their history and ethnography written for the Census Report of Burma, r 892 , by Dr. $J$. $N$. Cushing. In the present book the information thus collected has been carefuily summarised in two chapters on tribal history and literature by $\mathrm{Mr}$. IV. W. Cochrane.

Mrs. Leslie Milne spent about twenty months in a Shan village with the object of studying the language of the Palaung or Palè, a neighbouring hill tribe who

l "Shans at Home." By Mrs. L. Milne, With Two Chapters on Shan History and Literature by the Rev. W. W. Cochrane. Pp. xxiv +280 (London: J. Murray, igro.) Price i5s. net. 